\title{
NiETZSCHE’s IDIOSYNCRASY AgAINST EURIPIDES
}

\author{
Abstract
}

Lo scopo principale di questo articolo è presentare una critica alla lettura nietzscheana dello status valutativo della poesia di Euripide all'interno del processo storico-genealogico che il filosofo intende come costituente il declino della tragedia greca. Il carattere negativo - che presumibilmente radicalizza, rafforza e consuma questa ipotetica traiettoria di declino - della poesia euripidiana sarà qui imputato al condizionamento molto teorico della concezione nietzscheana del tragico. Per fare ciò, esploreremo tre linee guida fondamentali: (1) la subordinazione di Nietzsche a una linea interpretativa tradizionale; (2) il suo tendenzioso disprezzo per il contenuto concreto dell'intera opera euripidiana; (3) l'identificazione infondata tra Socrate ed Euripide.

The main purpose of this article is to present a critique of the Nietzschean reading of the evaluative status of Euripides' poetry within the historical-genealogical process that the philosopher understands as constituting the decline of the Greek tragedy. The negative character-supposedly radicalizing, potentializing and consuming this hypothetical trajectory of decline - of Euripidian poetry will here be imputed to the very theoretical conditioning of the Nietzschean conception of the tragic. To do this, we will explore three fundamental guidelines: (1) the subordination of Nietzsche to a traditional interpretative line; (2) his tendentious disregard for the concrete content of the whole Euripidian work; (3) the unfounded identification between Socrates and Euripides.

\section{INTRODUCTION}

Euripides' poetry suffers considerable historical depreciation through a critical lineage that goes from Aristophanes to the Schlegel brothers, passing through Herder and Winckelmann and finally being consummated in Nietzsche, expressly in Book XI of The Birth of Tragedy. ${ }^{1}$ Such damnatio is based mainly on the element of poetic rationalization. ${ }^{2}$ As far as Nietzsche is concerned, part of his criticism ends up being as negligent - or even more so, at certain times! - as the sarcasm staged by Aristophanes. ${ }^{3}$ Considering it as a whole, we understand that it cannot be sustained. ${ }^{4}$

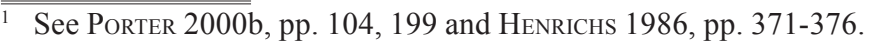

2 See Easterling - Knox 2008, p. 319.

3 «I am really amazed that the scholastic nobility does not comprehend his virtues, that they rank him below his predecessors, in line with that high-toned tradition which the clown Aristophanes brought into currency. Has any nation ever produced a dramatist who would deserve to hand him his slippers?» Goethe, apud SNELL 1953, p. 135. See also MurRaY 1913, p. 10. Letting himself be carried away by the fantasy of Aristophanes, Nietzsche came to believe that Euripides carried out «a conscious reaction against the Aeschylian Tragedy» (NIETZSCHE [I] 1999, p. 549). In no less inconsistent way, he also suggests that the poet has downgraded art to obtain the support of the crowd (ivi, p. 79). Obs.: the criticism becomes even more excessive when we consider that the comedian also ridiculed Socrates, since «Aristophanes suggests that Socrates was one of Euripides' sources of inspiration»! Américo Ramalho. In: ArISTófanes 2008, p. 139. See also Vogel 1966, p. 110. And Nietzsche even came to believe in Socrates' direct influence on Euripides, even though this supposed relationship could never be proven! See Nietzsche (I) 1999, p. 547 and SALLis 1991, pp. 123, 126.

4 See Vogel 1966, p. 19.
} 
In elaborating his conception of the tragic, Nietzsche reveals to us, through his analyzes, serious limitations that are still overlooked by many who believe that his interpretation came from a embracing knowledge about classical tragic poetry. ${ }^{5}$

Among these restrictions, the main one must be referred to the more general fact that his idea of the tragic, which the art of Euripides would hurt, revolves almost exclusively around the projection of the relation of forces between the Dionysian and the Apollonian at the expense of any other reference more thoroughly committed to the contents of the Greek tragedies themselves. ${ }^{6}$

\section{Genealogy of Degeneration}

In a posthumous note from the summer of 1875 , Nietzsche states that «Aeschylus also guarantees an elevation of the Greek spirit that perishes with him». ${ }^{7}$ Despite adopting the subjection of the terrific background of existence as the main index for the critical diagnosis of decadence of the tragic, Nietzsche, by «Die dionysische Weltanschauung», praises Aeschylus to the detriment of Euripides for having achieved «the sublime» by virtue of having presented a «norm of justice» that would have brought together «moral customs and blessedness». ${ }^{8}$ In these terms, Nietzsche passively chooses that critical tradition based on the moral condemnation of Euripides. He further exhorts the fact that punishment in Aeschylus is not a necessity. ${ }^{9}$ Rash damning judgment from which we can already infer two incongruities.

The first of these, internal to Nietzsche's own thinking, concerns the tacit adoption of caritas as an elective criterion. With this, ironically, Aeschylus theater would be more precious than Euripides because, with the first tragedyographer, «the popular faith is corrected», in the Christian way. ${ }^{10}$

The second incoherence, committed this time in disregard for the poet's own literary-theatrical production, is due to the lack of recognition that Euripides' plays present in a significant number and degree the adoption of a collusion between the gods and not only the hamartias committed by mortals as well as the hybris that characterize their tragic heroes. ${ }^{11}$

In view of this partiality, the recurrence to the introductory seminar on sofoclian poetry is justified as necessary, because through it we can observe that Euripides can only represent in a certain way a rupture insofar as at the same time he radicalizes a process that in a certain sense also retroacts on Aeschylus and Sophocles:

\footnotetext{
See HenRichs 1986, pp. 371, 381.

6 Ivi, pp. 384-385. «In "Birth of Tragedy" it wasn't really about the Attic tragedy». Vogel 1966, p. 182.

7 Nietzsche (VIII) 1999, p. 113.

8 Nietzsche (I) 1999, p. 568.

9 Ibidem.

10 Ibidem. Faith through which the Olympic gods would still have been rebuilt «in a strictly subjective community»; ibidem. Therefore, it will not be a coincidence that «he refers to the sublime gesture by which Apollo redeems the world of suffering» (SALLIS 1991, pp. 93-94).

${ }_{11}$ Medea is perhaps the most expressive case in this regard.
} 
With Euripides there is a rupture in the development of the tragedy - the same rupture that, at that time, shows itself in all forms of life. A powerful process of enlightenment wants to change the world according to thought; everything that exists succumbs to devastating criticism because the thought still develops unilaterally. The tragic poet, who has always been considered master of the people, transmits this new education. The impulse is given by Euripides [...]. Euripides' tragedy is the thermometer of the aesthetic and ethical-political thought of his time, as opposed to the instinctive development of ancient art, which came to an end with Sophocles, a transitional figure, as his thought still moves along the tracks of instincts, and in this sense he is a follower of Aeschylus. With Euripides a scission arises. Point of view without consideration or pity for the old. Where it seems necessary to him to criticize the former, he does so with shameless clarity. ${ }^{12}$

It is as if through Euripides, preceding Socrates, for the first time the theoretical man was prefigured: «With the ö $v \vartheta \omega \pi \circ \varsigma \vartheta \varepsilon \omega \rho \eta \tau 1 \kappa o ́ \varsigma$ the ancient world succumbs. The Apollonian element separates again from the Dionysian and now both degenerate». ${ }^{13}$

However, it failed to observe with this that the Prometheus of Aeschylus had already begun a criticism of the gods, as well as the Oresteia trilogy, of this same poet, had already revealed a strong process of objectification of the same. Criticism that can also be found, for example, in Aias, and objectification of the gods in Philoctetes, both of Sophocles. Therefore, it must be clear that Euripides can only be placed in confrontation with Aeschylus and Sophocles for having radically exposed an already incipient tension in the poetry of both. Tension that is essentially constitutive of the tragic universe and that therefore cannot have its vigor used to depreciate the tragedies through which it emerges in a radical way.

Nevertheless, when insisting with his kind of «genealogy of the tragic», Nietzsche acknowledged that the process of decline is a transition that already happens as a matter of fact in the passage from «lyrical tragedy» to «tetralogy according to Aeschylus». A moment when the most decisive change would have occurred through the following: «The unity of the whole no longer consists of the unity of a single event, but of an essence or thought (the lineage as a Platonic idea). The concrete unique event is increasingly volatile: finally, only one thought remains as a bond. The artistic force was introduced, then, in the individual drama. In overall, reflection dominates»». ${ }^{14}$

As an underlying motivation, Nietzsche imputes to the decadence pattern that he establishes for the classical Greek tragedy a metaphysical principle retroactive to poets and, to a greater degree, exogenous to poetic art by making it subject to theoretical conceptualization. Therefore, if we can clearly see that for Nietzsche «the error is here: the unity of tragedy is in thought», ${ }^{15}$ we must be able to extract from this evidence that such an error must be prospected at the bottom of the analytical references that condition his own idea of the tragic, by means of which he throws himself on the archaic tragediographers. Conditioning by virtue of which, «without altering his view

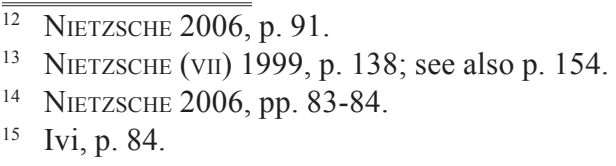


that Euripides is the decisive figure, Nietzsche sometimes suggests that the transformations that led from Aeschylean tragedy to the death of tragedy were already under way in Sophocles». ${ }^{16}$

In the case of Sophocles, the complaint was made against the «resignation» that accepts the immeasurable «distance between the human and the divine», through which an enlightening principle would begin to be inserted through the transposition of the tragic to «a failure of the knowledge». ${ }^{17}$ Although it still feeds on the «Dionysian truth» that makes this wisdom «unfathomable», this resource would be already contaminated by the «ethical principle of Apollo». ${ }^{18}$

In any case, the heart of the problem still rests, as we can see, in the gnosiological scope, as will be confirmed in paragraph 81 of the second book of Gaya Scienza: "In Sophocles at least "everything is proved"». ${ }^{19}$ This means that the Apollonian principle of clarifying the truth about the spiritual conditions of the elevation of the human that conflicts with his sensitive nature would become, under the feather of Sophocles, an element immanent to the tragic individual. Consequently, the distinction that Nietzsche drew between Aeschylus and Sophocles was guided by the following change: «The lack of man's knowledge about himself is the problem in Sophocles, the lack of man's knowledge about the gods, is the problem in Aeschylus» ${ }^{20}$ Thereby, Nietzsche also neglects the fact that the «know yourself!» precedent to Socrates presupposed a conception of daimon that did not yet establish a gnosiological dichotomy between man and divinity, in such a way that the mortal could not know his limits outside the relation with a sense that exceeds him. ${ }^{21}$

And even when posteriorly, by means of a kind of late palinody, Nietzsche grants Sophocles the right to restore the balance between the Apollonian and the Dionysian, ${ }^{22}$ he still does so by ignoring the fact that the possibility of the hermeneutic presence of this tension in the midst of the poems Sofoclians should not, in essence, still obey the dialectical movement yearned for by the philosopher, but rather the ambiguous character of the open poetic word.

In any case, that is, regardless of the oscillations of his position about the relation of meaning between the aeschlean and sofoclean poetry, the fact is that the expansion of the positive status of the tragic will end in the latter. ${ }^{23}$

The criterion for this is explicit precisely through the dualistic conflict between the logical knowledge restricted to the Apollonian and the sensitive impulses circum-

\footnotetext{
$\overline{16}$ Sallis 1996, p. 111. See also Porter 2000a, pp. 229-230, 236.

17 Nietzsche (I) 1999, p. 569. As if the outcome of Oresteia was also not marked by a resignation before a divine, ethical and political court!

18 Ibidem.

19 Nietzsche (III) 1999, p. 437.

20 Nietzsche (I) 1999, p. 570.

21 See Vernant - Vidal - Naquet 1990, pp. 35, 37, 45, 78; Aeschylus 1973, v. 719; Sophocles 2001, v. 1316-1317; WinNINGTON - INGRAM 1980, pp. 151, 177; STEINER 1984, pp. 90, 91; KirKWOOD 1994, p. 286; Jamme - Lemke 2004, pp. 392, 414, 425; Pridik 1998, p. 151; Beistegui - Sparks 2000, p. 195.

22 «In Sophocles' world intuition, both Apollo and Dionysus triumph again: they affiliate». NIETzSCHE (VII) 1999, p. 67; see also p. 81.

23 «Sophocles as the triumph of tragic thought». (ivi, p. 207). See also Sallis 1996, p. 111 and PorTER 2000a, pp. 229-230, 236.
} 
scribed to the Dionysian. With such radicalism and scope to the point of serving as a fundamental touchstone to establish the path of decline of the tragic idea among the three greatest tragedyographers in Ancient Greece: «Sophocles walks beyond Aeschylus' trail: until then, it was the artistic instinct of the tragedy that drove it; now is the thought. But in Sophocles the thought as a whole is still in agreement with the instinct; already in Euripides it becomes destructive in relation to the instinct». ${ }^{24}$

\section{The NieTZsChean Hyperbole}

We understand that this Nietzschean criticism would represent limitations due to the lack of observance of the more specific fact that the theoretical framework that the philosopher transfers to Euripidian poetry, namely, that «everything must be understandable so that everything can become understandable», ${ }^{25}$ it is generalizing because it disregards that, despite the strong rhetorical strake that permeates the speeches of his characters, the whole poetic conception of Euripides cannot be reduced to this stylistic element.

One of the problems that Nietzsche points out - and here we must agree with him - is that in the case of Euripides the dialectical artifice is not restricted to his exacerbation in the form of drama, but is also radically exercised in the rant of many of his characters. ${ }^{26}$ And this, taken in isolation, may in fact end up weakening the feeling of compassion that is essential to the economy of drama, and may even influence the effect that tragedy has on viewers. In this case, Nietzsche shows himself once again aligned with the interpretative tradition, this time that debtor of Aristotle, who through his Poetics instituted the catharsis as a central analytical reference.

However, for this partial and restrictive diagnosis to take on the appearance of wholeness, one must sweep under the carpet on which the philosopher walks the not less present Euripidian sticomities guided precisely by the confrontation between the passionality and the rationality that splits the spirit of many of their heroines and heroes who become emblematic in this respect, among which we could mention, albeit en passant, Macaria in The Heracleidae, Polyxena in Hecuba, Cassandra in The Trojan Women, Alcestis, Medea, Heracles, Iphigenia and Andromachae in their homonyms dramas. ${ }^{27}$

Moreover, and seen now in a broader way, the formal resource of structuring the unfolding of the facts that embody the scenic economy of the plays shaped by a certain logical sequence is as determinant for the Euripidian theater as it was also for the Aeschylean and for the Sophoclean. This is because the very creation of dramatic tension depends on a gradual and concatenated unveiling of events, a fundamental artifice

\footnotetext{
24 NieTzsche 2006, p. 83.

25 NietzSChe (I) 2009, p. 537. Or «everything needs to be conscious to be beautiful», which Nietzsche believes to be «the Euripidian premise parallel to the Socratic "everything must be conscious to be good"», which would make Euripides «the poet of Socratic rationalism» (ivi, p. 540).

26 See Nietzsche (I) 2009, p. 75.

27 Obs.: perhaps at this point in particular part of the blockade was due to the predominance of gender.
} 
for the construction process of the theatrical exhibition that inevitably tends to further objectify the mythic narrative of which it appropriates. In view of this, the statement that «Euripides is the first playwright to follow a conscious aesthetic $\rangle^{28}$ sounds naive to us. Even because of the obvious fact that no artist can completely dispense with any domain of pratical rules.

Therefore, it is not simply «his conscious knowledge» that guarantees Euripides «such a position worthy of consideration in the history of Greek art». ${ }^{29} \mathrm{In}$ this regard, neither does the technical innovation instituted by his theater, that is, that of anticipating the outcome of the drama already in the prologue to the plays, seems sufficient to reduce its poetic verve to a «rationalist aesthetic» that would make «the tragic compassion impossible», ${ }^{30}$ since this resource concerns only a formal resizing aimed at the synthetic anticipation of the senses to be explored throughout the staging. ${ }^{31}$

\section{The Resizing of Mythic Matter Through Euripidian Theater}

In the time when the tragedy ceases to be the execution of festive rituals (The Dithyramb) to become a theatrical staging in public contests, even though the festive date (The Dionysia) has been maintained, it objectifies itself in such a way that the appropriations of myths carried out through it are always unfolded based on a determined background reflection. And even before this rupture, it also seems to us that, in fact, one could defend the thesis that even the playful dazzle of the festivities could already be seen as a potentially Apollonian artifice:

When the Greek men feel that the march of the world leads everything to perish, they contemplate the Dionysian truth there: everything that exists one day will no longer exist. The parties in honor of the god Dionysus come to seek, behind this revelation, a joy that allows them to comfort themselves with the nature. Believing that the satyrs also did this in forming the choir, they saw in this celebration a way of not succumbing to such a cruel view of the world. As well as their understanding of the satyrs, they also felt their strongest emotions re-

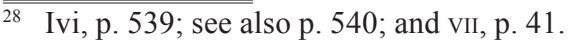

29 NieTzsche (I), 2009, p. 86.

30 Ivi, pp. 537, 538.

31 «From one perspective, Aphrodite's appearance on stage at the opening of the play tells us everything we need to know about the end of the play. However, within the scope of this determined end, the range of decisions made by the characters is remarkable». (BRILL 2007, p. 288). Obs.: against the argument that such an appeal would make «tragic compassion impossible», just look at the following: «Much was questioned about the importance of this monologue, since Aphrodite tells what will happen in Hippolytus. However, it is necessary to pay attention to an essential fact: the goddess does not say precisely how Phaidra's love for Hippolytus will be the ruin of both, nor does she say what will become of Theseus and how he will become aware of everything, nor does she mention the nurse, the connecting point of events. By omitting such information, the monologue, contrary to what it may seem, intensifies the suspense, the mystery, thus serving to increase the tension of the audience and the reader» (RAgusa 2003, p. 93). To a broader defense, see Murray 1913, pp. 208-211. «From one perspective, Aphrodite's appearance on stage at the opening of the play tells us everything we need to know about the end of the play. However, within the scope of this determined end, the range of decisions made by the characters is remarkable» (BRILL 2007, p. 288).
} 
stored in the services that yielded to divinity through the choir. ${ }^{32}$

The objective apprehension of physis could only occur through the development of a reflexive logos that also included poiésis as a techné inserted in this period of transition. Thus, the theatrical appropriation of religious rituals obeys the stated purpose, in virtue of which Dionysus is also subjugated by Apollo. From this perspective, the correct conclusion is that «Nietzsche interprets the formation of the Dionysian choir as the solution that the Greeks found for the problem of pain and contradiction in the world. [...] As in the Apollonian arts, the Dionysian cults should serve the Greeks as a form of transfiguring reality». ${ }^{33}$ Therefore, if logical affectation can be understood as a form of superposition of sense, the formalization of mythic matter through the dialectic resource would represent a kind of repotentialization of the meaning implicit in the myth: «Now, we saw earlier that art is the stratagem used by the Greek men to organize the chaos that is the world of becoming. They did not succumb precisely because the various artistic forms gave them a view of the world with which it was possible to endure the reality. In this sphere, the Greek tragedy represented, in the first place, a salvation for the mythology itself $\gg .{ }^{34}$ In this context, the resizing of tragic art undertaken by Euripides should be considered as an extension of the reach of mythical matter to the present reality.

\section{The Reduction of Sense of the Gods}

Another element that Nietzsche uses to attack Euripides, the redemptive outcome, which would have caused «the tragedy to perish through an optimistic dialectic and ethics», ${ }^{35}$ is not exclusive to the Euripidian theater. Besides, it is not a sine qua non factor for his poetry as a whole. For if so, the philosopher himself could not even resent that divine benevolence, present in Aeschylus and supposedly lacking in Euripides, as we have already pointed out. ${ }^{36}$ Therefore, also on this point he would have missed the poetic ambiguity. Ambivalence that would be enough to question this supposed optimism.

As if that were not enough, we must also emphasize the warning that, technically speaking, «Euripides employed the deus ex machina not as a finality, but as a means». ${ }^{37}$ Consequently, even if it is undeniable that the resource of deus ex machina represents, in its underlying sense, a clear appeal to the divine guarantee that becomes certain as the upshot is anticipated by the prologue, in such a way that the drama must be subordinated to this predetermined final purpose, this admission still does not seem suf-

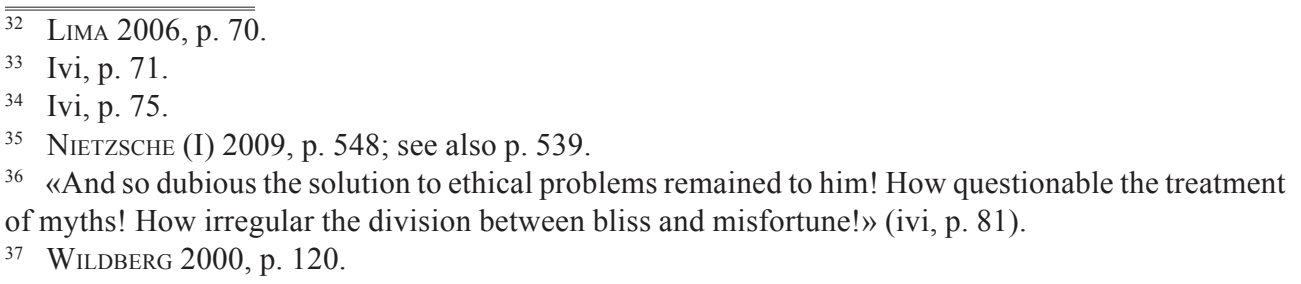


ficient for the exaggerated anachronism of making the poet Euripides, only through this artifice, «similar to Descartes, who could be assured of the reality of the empirical world only by appealing to the truth of God and his impossibility to lie». ${ }^{38}$ Even because the Euripidian deity also proves capable of deceiving, as it appears, for example, in the Ion.

Therefore, we can see that, once again, Nietzsche prematurely applies an overly philosophical schema to the poet. Such an incoherence that would not have occurred if Nietzsche had taken into account two exponential works: Medea and The Bacchae, in which the appeals to deities, whether ex machina or not, do not incur redemptive denouement, quite the contrary.

In the case of this last play, it is even the one that is considered the main work of Euripides and that Nietzsche did not properly consider, despite being the only remaining Attic tragedy that addresses the myth of his dear Dionysus. An oversight that, as we also believe, would have occurred due to the biased formal project set up in Die Geburt der Tragödie:

The genesis and construction of this book is somewhat delicate. As Henrichs analyzes, Nietzsche's case is very curious, because, due to the fact that he highlighted Euripides' rationalism, and established a connection between him and Socrates, he had to give up his positive comments about The Bacchae (presented in the Course of 1870) in The Birth of Tragedy, in which he had made the "idea of the tragic" and the "idea of the cult of Dionysus" equivalent, since, otherwise, it would fall into contradiction. The decision to detach the discussion on the Bacchants from their representation of the Dionysian $(B T, 1-10)$ and to include it in his criticism of Euripides (BT, 11-13) would have been, according to Henrichs, an unfortunate decision, since Nietzsche could have made better use of this piece to support his own conception of the Dionysian experience. In fact, the so-called "Theory of Palinodia", which Nietzsche used to solve the paradox of having Euripides written (at the end of his life) a play dedicated to the cult of Dionysus, did not solve the inconsistency in his text. ${ }^{39}$

Also at the bottom of the palinodic thesis lies the Nietzschean idiosyncrasy, because, so that the recognition of the Dionysian power present in The Bacchae would not demolish the whole theory of the decline of the tragedy erected by the philosopher, it was more convenient to attribute to this work a character of recantation thus reinforcing the validity of his own theoretical speculation. ${ }^{40}$ Thus the Nietzschean bias about Euripides was already so committed by the need to justify and affirm his own incipient theoretical project that even the explicit acknowledgment that the god presented by Euripides in The Bacchae «is too powerful» ${ }^{41}$ was not enough to curb such skew. ${ }^{42}$

\footnotetext{
$\overline{38 \text { Nietzsche (I) } 2009}$, p. 86.

39 Maria Coelho, in BocaYuva 2011, pp. 126-127. See also Henrichs 1986, pp. 391, 396.

40 Ivi, p. 393.

41 NietzSChe (I) 1999, p. 82. Obs.: also later, in a posthumous fragment (4[9]1870), we can find another admission that «Euripides' Bacchae» would have «made a strong impression on him and aroused pleasure» (NiETZSChe [VII], 1999, p. 91).

42 «In the end, however, his bias against Euripides led him to divorce his guarded comments on the Bacchae as a tragedy from his enthusiastic evocation of the powerful emotional effect experienced by the worshippers of Dionysus. Without the help of the Bacchae, Nietzsche could not have appreciated this effect. Yet his debt to Euripides is never made explicit, least of all in BT» (HENRICHS 1986, p. 379).
} 
This is because Nietzsche also introjected here the projection of an inversion by passively accepting the traditional interpretative tendency that classifies The Bacchae as a kind of retraction of the poet:

\begin{abstract}
the quote to Euripides in section $\S 5$ of The Birth of Tragedy goes through an apparently antithetical view of Nietzsche about the Greek theatrologist, since for him The Bacchae is the maximum Dionysian work and its author is the corruptor of the tragic spirit because of his previous works. [...] For the German philosopher, Euripides would have recognized at the end of his life the mistake in corrupting the Dionysian spirit of the Greek tragedy, and The Bacchae would be an ode and a retraction to Dionysus, however, such a late change in Euripides was not able to interrupt the process of degeneration that he had started in the Greek theater. ${ }^{43}$
\end{abstract}

\title{
The Cicuta that Nietzsche Offers to Euripides as a Lenitive from Himself
}

In The Birth of the Tragedy, Nietzsche uses his interpretive key to criticize Euripides based on the problem of pessimism and the spirit of music. The philosopher makes comments on Euripides' art without, at any time, referring in particular to his plays. ${ }^{44} \mathrm{In}$ view of this, we do not hesitate to affirm that what Martin Vogel points out in Nietzsche about his troubled relation with Schopenhauer could be more appropriately extended to his considerations about Euripides than to the aforementioned thinker: «Nietzsche wrote about a philosopher that he did not know, that he did not even want to know, because such knowledge did not seem convenient to him». ${ }^{45}$

By pulling Euripides out of his original context to subordinate him to a philosophical analysis and, with this, not recognizing him as an exponential artistic index of a space of crisis that opens between the tradition of poetic appropriation of myth and the incipient philosophical rationality, Nietzsche, because of all his opposition to Socrates, created an excessive approximation between the poet and the philosopher. ${ }^{46}$

The curious thing is that Nietzsche will admit that his criticism against Socrates focuses on the discomfort of this representing «a cure». ${ }^{47}$ From this we can also glimpse a kind of antinomy in virtue of the fact that the relationship between the Apollonian and the Dionysian that gives nuclear support to the project of The birth of Tragedy is primarily aimed at restoring the «overflowing health of the Greeks» by means of a wholesome soothing extracted from the Apollonian domain. And again it seems to us that this yearning can also be inferred as a psychic projection channeled to the figu-

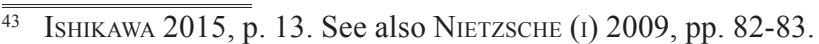

44 Obs.: Nietzsche's basic disregard for his treatment of tragedies is also evident when he, in the lecture of the summer semester of 1870, at the University of Basel, affirms that «the deus ex-machina already exists in Sophocles», thus ignoring the outcome of Oresteia! (NIETzsche 2006, p. 92). To learn more about how Nietzsche intentionally ignored Euripides' work, see HeNRICHs 1986, pp. 377, 382.

45 Vogel 1966, p. 186. «His treatment of Euripides suggests that he had barely read the author of whom he was so critical, and that such limited knowledge as he did have was for the most part secondhand and derived from Schlegel». (HenRICHs 1986, p. 382).

46 Ivi, pp. 386-388.

47 NieTzSche (VIII) 2009, p. 228.
} 
ration of a Socrates that corresponds to a personal demand of the philosopher, generating distrust about the
fact that he invented the "free spirits" as a kind of "therapeutic interlocutors" who helped him to endure his own disease. In this regard, Nietzsche prescribes in Ecce Homo: "I took myself in hand, I healed myself: the condition for this - any physiologist will admit - is to be really healthy" "Why am I so wise" §2). Taking into account, as Nietzsche himself asserts, that the free spirits are nothing more than "therapeutic interlocutors", it is possible that such a com- parison is only an anesthetic, in other words, that the Socratic freedom described by Nietzsche was just a moment of "rest" or "cure" by Nietzsche himself who restored his strength. Using Deleuze's language, Socrates' free spirit was a "conceptual character" created by Nietzsche to make his own existence more enjoyable. ${ }^{48}$

This apparent ambiguity between Nietzsche's love and hate for Socrates can be captured in a dialectical dynamics internal to the spirit of the German thinker. ${ }^{49}$ This in such a way that the Socrates built by Nietzsche

is also the embodiment of the Nietzschean ideal: the suffering man who can keep his pain under control. Nietzsche found in him, as well as in Goethe, a man to whom he gave "his character and style" (FW 290) and for which "he became disciplined for the whole" (GD IX 49). Undoubtedly, such men live above all on the threshold of what Nietzsche called "décadence"; and they carried out their great works of self-creation and self-unification in terms of dissolution and solution..$^{50}$

Nietzsche thus unfolds in his Socrates his own most intimate struggle. Conflict explicitly assumed by its own passive agent: «Socrates, just to confess, is so close to me that I almost always fight him». ${ }^{51}$

Now, if Euripidian poetry was over-affected by Socratic logic, and if this ultimately ends up imposing itself as a condition for human life to subsist to its own sensitive impulses, a necessary and singular greatness must be seen in the poet. ${ }^{52}$

However, the breadth of conceptualism attributed by Nietzsche to «Socratism» makes the philosopher use this categorization to absorb and reduce all the artistic genius of Euripides:

So the content of this archetype in its essential components also in Nietzsche would not be absolutely attached to the figure of Socrates. Even before Socrates emerged, there would have been an "anti-Dionysian tendency", which would have driven the scientific thought. Already in Sophocles "the Dionysian soil of tragedy" had begun to be undermined. [...] In a general way, science, before Socrates, had dominated the field of the arts. It arises in its original productive form as a movement that is independent of a single person. It appears as the product of a collective power. Nietzsche calls this power Socratism and says that it would be something "like an extraordinary driving force" at work behind Socrates and that through its man-

\footnotetext{
48 Douglas Meneghatti in Carvalho - Frezzatti 2015, p. 290.

49 See Henrichs 1986, pp. 385-386.

50 Kaufmann 1982, p. 464.

51 NietzSche (VII) 2009, p. 97. «Nietzsche's Socrates is ultimately a name for this very gap». Porter 2000 b, p. 191.

52 «He writes that in the greatest human beings we find the most powerfully conflicting instincts under control». (NeHAMAs 1985, p. 227).
} 
ifestation it should be contemplated "as if through a shadow". Socrates is only the exponent. His name is a cipher. As an exponent, as a cipher, the Socratic form in Nietzsche becomes the background archetype for Euripidian drama. ${ }^{53}$

In a general way, this strong idiosyncratic character of Nietzschean ideas (which seems to predominate throughout his entire biography and which is revealed through his relationship not only intellectual but even passional about figures like Schopenhauer, Wagner, Socrates/Plato, Euripides, Goethe, among others) really lead us to believe that «many of his philosophical duels are nothing but the visible expression of internal conflicts, of crises of growth of his own theoretical programs» ${ }^{54}$

The strong physiological tendency of Nietzschean thought seems to tacitly coerce its author to always merge in some way with his objects of criticism. ${ }^{55}$ Consequently, we adopt here the suspicion that, at least with regard to the exercise carried out in Die Geburt der Tragödie, both about the figure of Socrates and that of Euripides, «what emerges from an analysis of Nietzsche's early writings is not only a practice of critique but a theory of subjective identity». ${ }^{56}$

Meanwhile, as such identification is radically conflicting, this conflict seems to have created an obstacle to the need to assume the gap resulting from a philosophical appropriation of the poetic, in addition to preventing Nietzsche from locating in the Euripides theater the strong elements of Dionysian appeal.

Our diagnosis then is that there would only be a Socratic tendency in Euripides because there was rather an Apollonian propensity in the way Nietzsche himself apprehends the playwright's poetry associated with his reaction to the resentment of an unrealizable Dionysian state.

\section{CONCLUSION}

Nietzsche seeks art driven by an unrealizable philosophical longing. Subject to this claim, it is clear that a «objective art», taken to the stage, closed in a historical context, could not meet the metaphysical demands of a philosopher desiring an irrecoverable vital impulse as such. Hence the need to recreate a myth. The aggravating factor, in the case of the young man who wanted to stop being a philologist, but who still could not assume himself as a philosopher or even make himself an artist, was to wait for the Greek poets to passively subordinate themselves to a metaphysical principle that the philosopher lodges in the myths from which these poets had to let go in order to carry on the tragic art, while, against the grain, the philosopher violates the myths to try to find in it a metaphysical principle, only before which the art, for him, could become valid. ${ }^{57}$ It is by obeying this exigency that the tragic art must be able to present

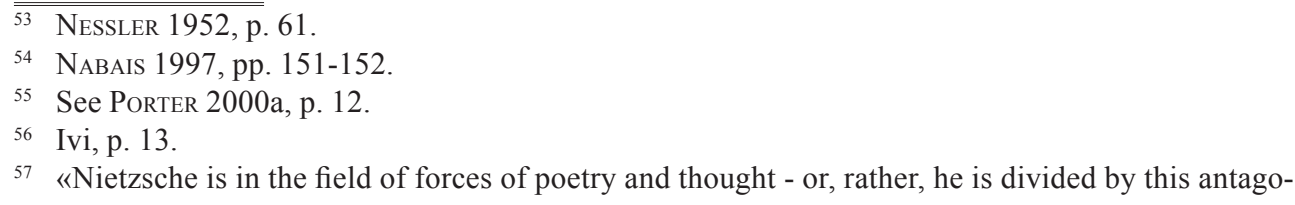


a «justification of the world»: showing that the «phenomenon», in its highest aspect, is always an «illusion». ${ }^{58}$ Thus, as we tried to denounce, what Nietzsche did was to present a conception of the tragic that obeyed a certain philosophical principle detached in a concrete way from the artistic phenomenon from which he believes to depart and on which it focuses.

In the conference entitled Socrates und die Tragödie, published as posthumous writing, Nietzsche came to recognize in Euripides a certain «reaction against the supposed decadence» ${ }^{59}$ However, this attempt at «reaction» presented itself to his eyes precisely as «the beginning of the end». ${ }^{60}$

But the strongest element of relativization that can be found in Nietzsche about his conflict with the theater of Euripides is in an admission recorded in a later commentary on that conference, which can still be understood as a kind of self-criticism about what had been your diagnosis in relation to the poet: «It is the most unfair ignorance to consider him as the root and cause of this decadence: he is much the first to recognize it and to seek to combat it amidst the contradictions of the so-called scholars of his time». ${ }^{61}$

We understand that this mea culpa was due to the fact that Nietzsche reduced Euripides' art by standardizing it in submission to his own theoretical principle. What he imputed to the poet was, in the end, what conditioned his own philosophical vision, because «he allows that in Euripides the logical impulse overcomes the mythical». ${ }^{62}$ Nietzsche resents a demand that was not imposed on Euripides, since the poet, as a paradigmatic exponent of a period of changes in the artistic way of appropriating the myth, could not yet propose himself to a role of restoring the tradition from which he needs to break free in a certain extent to advance his artistic genius.

In the condition of those who takes to the stage in a vehement manner the tensions that account for the risk of resizing the traditional mythical universe, it is inevitable «Perhaps now I have become more careful and less confident in talking about psychological issues as difficult as the Greek tragedy was born. A fundamental question is the relation of the Greeks with pain, their degree of sensitivity and whether their aspiration for beauty results from a yearning for self-deception in appearance, from a reluctance against the "truth" and the "reality". I once believed in that; now I would find it an expression of personal romanticism (- for which I was condemned for a moment to have been subjugated to the magic of all romantics until then)» (ivi, pp. 43-44). Conditioning that had been made explicit in Götzen-Dämmerung (\$24): «What does the tragic artist communicate about himself? Isn't it just the situation without fear in the face of the fearful and uncertain that he shows? - This same state is of a character of high desire; he who knows it glorifies it with the highest honors. He communicates it, he must communicate it, assuming he is an artist, a genius in communicating. The bravery and freedom of feeling in the face of a powerful enemy, in the face of a high setback, in the face of a problem that arouses terror - it is this victorious condition that the tragic artist chooses, glorifies» (NIETZSCHE [VI] 2009, pp. 127-128).

62 FINK 1992, p. 30.
} 
that Euripides would present himself as the antipode of the Nietzschean hypostasis of the need to restore an alleged condition of «overflowing health» belonging to the imaginary ideational that the philosopher retroactively imputes to the Greeks from somewhere motivated by the very crisis of classicism of his time. By introjecting this conflict with radicalism exacerbated to the point of making it unsustainable for himself, Nietzsche transfers this guilt to the one who vigorously expressed this critical dimension through his art. ${ }^{63}$ We understand that it is in this context that we must place the following diagnosis as to the psychological background motivation for this type of appropriation: «For his antipathy toward Euripides is actually directed against one side of his own personality. With the merciless scalpel of his critique he cut through the illusions, the dreams and hopes on which men support themselves; there remained to him a longing for naive health and vigour, a craving for genuine art which, like Schlegel, and Herder before him, he regarded as a creation from the recesses of myth». ${ }^{64}$

Here the psychologism employed by Nietzsche for the construction of his conception of the tragic must turn to its own author. This is because the quoted judgment seems to find a place in some of the philosopher's appraisals about Euripides, such as when he, for example, expresses the following complaint against the poet: «with him, however, the Hellenes gave up the belief in their immortality, not only the belief in an ideal past, but also the faith in an ideal future». ${ }^{65}$ This assertion is clear with regard to a certain form of ideality taken as an analytical criterion for an art that, in its originally tragic conception, could not yet be molded under the anvil of any «Classicism», since its essential goal implied precisely in reflecting the crisis of the spirit of its time, free from the need to present a soteriological solution to these changes.

\author{
Daniel da Silva Toledo \\ dasilvatoledo@yahoo.com.br
}

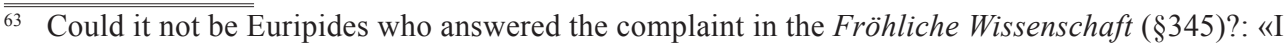
don't see anyone who has dared to criticize the judgment of moral values» (NIETZSCHE [III] 1999, p. 578). «One could argue that Nietzsche's postulate, that tragedy could and should reconstitute itself after the spirit of enlightenment has deconstructed itself by the recognition of its own limitations, is essentially already embodied in some Euripidean plays. The ascent of humans to the level of moral understanding and autonomy does not, as Socrates supposed, lead to a life that ceases to be tragic». Christian Wildberg. In: Cropp - LeE - SANSONe 2000, p. 244.

64 SNeLl 1953, p. 134.

65 Nietzsche (I) 1999, p. 78. «The ideality withdrew from the word and escaped the thought». (ivi, p. 534).
} 


\section{BIBLIOGRAPHICAL REFERENCES}

Aeschylus 1973 : Aeschylus, Seven against Thebes, translated by H. Bacon, Oxford, Oxford University Press, 1973.

AristóFAnes 2008 : Aristófanes, As rãs, ed. and transl. by A. de Costa, Lisboa, Edições 70, 2008.

Beistegui - Sparks (eds.) 2000: M. Beistegui - S. Sparks (eds.), Philosophy and Tragedy, London, Routledge, 2000.

Bocayuva (org.) 2011 : I. Bocayuva, Filosofia e Arte na Grécia Antiga, Rio de Janeiro, Nau, 2011.

BriLl 2007 : S. Brill, Aphrodite's Wrath: Eros in Euripides's Hippolytus, «Symposium»11, 2 (2007), pp. 275-295.

Carvalho - Frezzatti (orgs.) 2015 : M. Carvalho - W. Frezzatti (orgs,), Nietzsche, São Paulo, Anpof, 2015.

Cropp - Lee - Sansone (eds.) 2000 : M. Cropp - K. Lee - D. Sansone, Euripides and Tragic Theater in the Late Fifth Century, Illinois, University of Illinois Library, 2000.

EASTERLING - KNOx 2008 : P. Easterling - B. Knox, The Cambridge History of Classical Literature, I, Greek Literature, Cambridge, CUP, 2008.

FINK 1992 : E. Fink, Nietzsches Philosophie, Stuttgart, Kohlhammer, 1992.

Henrichs 1986 : A. Henrichs, The Last of the Detractors: Friedrich Nietzsche's Condemnation of Euripides, «Greek Roman and Byzantine Studies» 27, 4 (1986), pp. 369-397.

IsHIKAWA 2015 : Í. Ishikawa, A imagem do meio-dia nos escritos de Nietzsche sobre a tragédia, «Estudos Nietzsche» 6, 1 (2015), pp. 8-26.

JAMme - LemKe 2004 : C. Jamme - A. Lemke, «Es bleibet aber eine Spur/Doch eines Wortes». Zur späten Hymnik und Tragödientheorie Friedrich Hölderlins, München, Wilhelm Fink, 2004.

Kaufmann 1982 : W. Kaufmann, Nietzsche. Philosoph, Psychologe, Antichrist, Darmstadt, Wissenschaftliche Buchgesellschaft, 1982.

Kirkwood 1994 : G. Kirkwood, A Study of Sophoclean Drama, New York, Cornell University Press, 1994.

Lima 2006 : M. Lima, As máscaras de Dioniso. Filosofia e tragédia em Nietzsche, Ijuí, Unijuí, 2006.

Murray 1913 : G. Murray, Euripides and his Age, London, Williams \& Norgate, 1913.

Nabais 1997 : N. Nabais, Metafísica do Trágico. Estudos sobre Nietzsche, Lisboa, Relógio D’Água, 1997. 
Nehamas 1985 : A. Nehamas, Nietzsche. Life as Literature, London, Harvard University Press, 1985.

Nessler 1972 : B. Nessler, Die beiden Theatermodelle in Nietzsches «Geburt der Tragödie», Meisenheim am Glan, Anton Hain, 1972.

Nietzsche 1999 : F. Nietzsche, Sämtliche Werke. Kritische Studienausgabe in 15 Bänden, ed. by G. Colli und M. Montinari, Berlin, De Gruyter, 1999.

Nietzsche 2006 : F. Nietzsche, Introdução à Tragédia de Sófocles, Rio de Janeiro, Zahar, 2006.

Porter 2000a : J. Porter, Nietzsche and the Philology of the Future, California, Stanford University Press, 2000.

Porter 2000b : J. Porter, The Invention of Dionysus. An Essay on The Birth of Tragedy, California, Stanford Universitiy Press, 2000.

Pridik 1998 : K. Pridik, Das Tragische in den Tragödien des Aischylos, Sophokles und Euripides, I, Einführung und Aischylos, Vorlesung im Wintersemester 1997/1998 und Sommersemester 1998, 1998, Kirchliche Hochschule Wuppertal.

Ragusa 2003 : G. Ragusa, Cólera, paixão e morte: a representação de Afrodite no Hipólito de Eurípides, «Classica» 15, 16 (2003), pp. 79-98.

Rudnytsky 2002 : P. Rudnytsky, Freud e Édipo, São Paulo, Perspectiva, 2002.

SAluis 1991 : J. Sallis, Crossings. Nietzsche and the Space of Tragedy, Chicago, The University of Chicago Press, 1991.

Snell 1953 : B. Snell, The Discovery of the Mind. The Greek Origins of European Thought, Oxford, Basil Blackwell, 1953.

SopHOCles 2001 : Sophocles, Philoctetes, Cambridge, CUP, 2001.

Steiner 1984 : G. Steiner, Antigones. How the Antigone Legend Has Endured in Western Literature, Art, and Tought, London, Yale University Press, 1984.

Vernant - Vidal - Naquet 1990 : J. Vernant - P. Naquet, Mith and Tragedy in Ancient Greece, New York, Zone Books, 1990.

Vogel 1966 : M. Vogel, Apollinisch und Dionysisch. Geschichte eines genialen Irrtums, Regensburg, Gustav Bosse, 1966.

WildBerg 2002 : C. Wildberg, Hyperesie und Epiphanie. Ein Versuch über die Bedeutung der Götter in den Dramen des Euripides, München, Beck, 2002.

Winnington-Ingram 1980 : R. Wnnington-Ingram, Sophocles, Cambridge, CUP, 1980. 